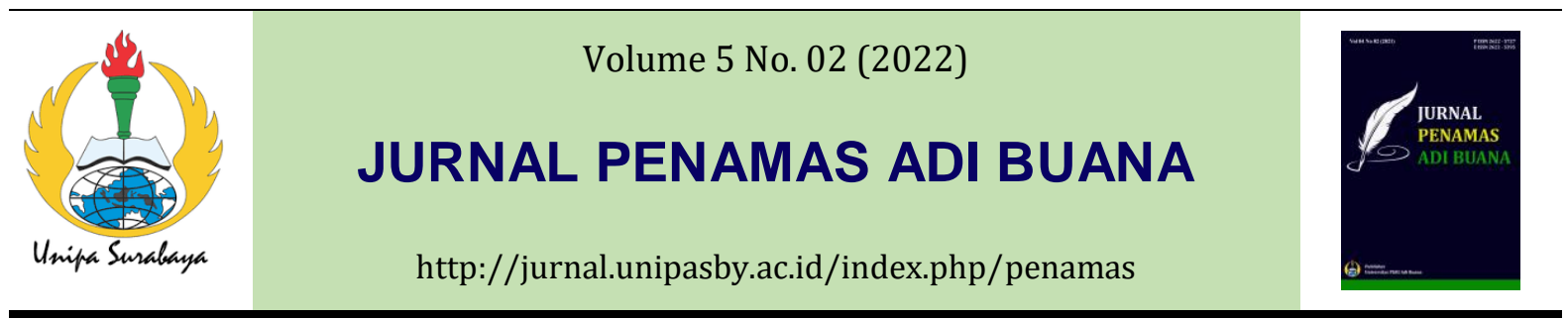

\title{
TEKNOLOGI TEPAT GUNA PAKAN IKAN OTOMATIS UNTUK PETERNAKAN LELE DIDESA BANJARKEMANTREN KECAMATAN BUDURAN KABUPATEN SIDOARJO
}

\section{Andarmadi Jati Abdhi Wasesa ${ }^{1}$, Titik Koesdijati ${ }^{1}$, Indra Dwi Febryanto ${ }^{1}$, M. Nushron ${ }^{1}$ Ali Mukhtar ${ }^{1}$}

${ }^{1}$ Program Studi Teknik Industri, Universitas PGRI Adi Buana, Surabaya, Indonesia

*Email: andarmadi@unipasby.ac.id

\begin{abstract}
Informasi Artikel Abstrak
Kata kunci:

Teknologi Tepat Guna, Perikanan

Diterima: 14-09-2021

Disetujui: 05-01-2022

Dipubikasikan: 31-01-

2022

Peningkatan penduduk di daerah tepi perkotaan, seperti di sidoarjo, membuat kebutuhan akan pangan juga semakin meningkat. Dengan berubahnya fungsi lahan menjadi perumahan, maka lahan pertanian akan semakin terkikis. Sumber pangan selain dari pertanian yang bisa dikembangkan adalah perikanan. Budidaya perikanan, terutama lele, tidak membutuhkan lahan yang terlalu luas, sehingga bisa diaplikasikan ke daerah perkampungan yang minim lahan kosong. Selain minimnya lahan, hal lain yang menjadi permasalahan adalah tenaga kerja. Semakin sedikit tenaga kerja yang ada untuk mengelola peternakan lele, membuat biaya tenaga kerja semakin meningkat. Hal ini bertentangan dengan potensi perkembangan permintaaan yang semakin meningkat. Apabila potensi tidak diiringi dengan inovasi maka akan menyebabkan bisnis tidak kompetitif. Dengan adanya teknologi yang bisa membantu pengelolaan peternakan lele, akan menambah nilai tambah bagi produk perikanan desa setempat. Teknologi yang sangat dibutuhkan adalah teknologi untuk membantu pemberian pakan, disebabkan ikan lele yang sangat sensitif terhadap jadwal pemberian pakan. Arduino sebagai perangkat mikrokontroller bisa diaplikasikan sebagai perangkat otomasi untuk meningkatkan produktivitas lele.
\end{abstract}

Keywords :

Appropriate

Technology, Fisheries

\footnotetext{
Abstract

The increase in population in suburban areas, such as in Sidoarjo, makes the need for food also increases. By changing the function of land into housing, agricultural land will be increasingly eroded. Food sources other than agriculture that can be developed are fisheries. Aquaculture, especially catfish, does not require a large area of land, so it can be applied to rural areas with minimal vacant land. In addition to the lack of land, another thing that becomes a problem is the workforce. The less manpower there is to manage the catfish farm, the higher the labor cost. This is contrary to the potential development of increasing demand. If the potential is not accompanied by innovation, it will cause the business to be uncompetitive. With the technology that can help manage catfish farms, it will add added
} 
value to local village fishery products. The technology that is really needed is technology to help with feeding, because catfish are very sensitive to feeding schedules. Arduino as a microcontroller device can be applied as an automation device to increase catfish productivity.

\section{PENDAHULUAN}

Desa Banjarkemantren merupakan salah satu desa yang terletak di Kecamatan Buduran Kabupaten Sidoarjo Jawa Timur. Desa Banjarkemantren terdiri dari empat dusun yaitu Dusun Banjar, Dusun Pandean, Dusun Kemantren, Dusun Jambe, dengan luas tanah kurang lebih 114.385 Ha. Sedangkan data penduduk menurut administrasi Desa Bajarkemantren sampai dengan tahun 2020 tercatat ada 6.685 jiwa terdiri dari 4615 Kepala Keluarga yang meningkat setiap tahunnya. Dengan peningkatan tersebut, dibutuhkan sebuah solusi untuk meningkatkan perekonomian masyarakat setempat

Ikan lele sebagai salah satu komoditas perikanan di desa Banjarkemantren sidoarjo membutuhkan sebuah strategi pengelolaan yang tepat. Lele harus diperhatikan waktu pemberian pakan agar ikan tersebut mendapat makanan yang teratur dan kontinyu. Kondisi topologi desa Banjarkemantren yang luas dan memiliki sumber air yang melimpah membuat desa ini memiliki potensi pengembangan sektor perikanan air tawar. Sektor perikanan memiliki berbagai macam manfaat bagi masyarakat setempat, selain manfaat utama sebagai pembantu perekonomian masyarakat, juga sebagai sumber pangan. Permintaan ikan sebagai sumber protein dan nutrisi lainnya meningkat seiring pertumbuhan penduduk dan kesadaran masyarakat akan gizi (Ramadhan \& Trilaksana, 2019). Masyarakat Banjarkemantren mulai sadar akan hal ini, ditandai dengan beberapa masyarakat yang sudah mulai membudidaya ikan lele dan ikan air tawar lainnya. Dukungan lain terhadap sektor ini didapat dari pemerintah lewat Kementrian Kelautan dan Perikanan diberikan lewat bantuan berupa freezer melalui BUMDes. Sedangkan dari segi peningkatan produktivitas hasil panen belum ada dukungan dari pihak lain, sehingga peternak lele masih beterenak dengan cara konvensional.

Peningkatan produktivitas bisa dicapai dengan penerapan teknologi pada salah satu aktivitas pengelolaan peternakan (Sundari \& Priyanto, 2016). Aktivitas yang membutuhkan perhatian khusus adalah pemberian pakan (Lazuardi \& Sudarto, 2017). Penggunaan sistem pemberian pakan lele konvensional memiliki beberapa kelemahan, yaitu sering terjadinya kelalaian pada penjadwalan dan juga tidak adanya pengontrolan takaran pada setiap pemberian pakan. Hal tersebut dapat mengakibatkan ikan kekurangan gizi, pertumbuhannya terhambat, kerdil, sakit dan bahkan bisa mengakibatkan kematian sehingga hasil panen ikan tidak maksimal (Pramono et al., 2020). Sebagai upaya untuk mengatasi hal tersebut maka perlu dibuat alat pemberi pakan ikan otomatis. Sehingga 
dengan hadirnya alat pemberian pakan ikan secara otomatis dapat dilakukan pemberian pakan yang akurat sesuai dengan jadwal dan mengurangi permasalahan dan kegagalan yang terjadi saat panen (Purwati et al., 2018). Dari segi biaya, alat pemberi pakan otomatis akan dapat meningkatkan efisiensi dan efektivitas pengelolaan tambak, sehingga tidak memerlukan tenaga ekstra (Wahyuni et al., 2018). Diharapkan dengan berkurangnya biaya pengelolaan maka harga jual lele produksi Desa Banjarkemantren akan semakin kompetitif.

Arduino adalah jenis software pengendali mikro berupa single dengan lisensi open- source yang merupakan turunan dari Wiring Platform (Hughes, 2016). Tujuan dirancangnya Arduino adalah untuk memudahkan penggunaan rekayasa elektronik untuk diaplikasikan pada berbagai bidang. Hardwarenya memiliki prosesor Atmel AVR dan softwarenya memiliki Bahasa pemrograman sendiri. Mikrokontroler itu sendiri adalah chip atau IC (Integrated Circuit) yang bisa deprogram menggunakan computer (Widodo et al., 2019). Tujuan menanamkan program pada mikrokontroler adalah agar rangkaian elektronik dapat membaca input, memproses input tersebut dan kemudian menghasilkan output sesuai yang diinginkan. Jadi mikrpokontroler bertugas sebagai otak yang mengendalikan input, proses dan output sebuah rangkaian elektronik (Abdullah \& Priyati, 2016). Karena komponen utama Arduino adalah mikrokontroler, maka Arduino dapat deprogram menggunakan computer sesuai kebutuhan. Bahasa pemrograman Arduino sendiri adalah Bahasa C. tetapi Bahasa ini sudah dipermudah menggunakan fungsi-fungsi yang sederhana sehingga pemula pun bisa mempelajarinya dengan cukup mudah (Erawati Dewi, 2012).

Alat pemberi pakan ikan otomatis berbasis arduino ini sangat diperlukan oleh peternak lele dalam mengelola kolam lele. Dengan menggunakan alat ini, pemilik kolam tidak perlu menambah tenaga kerja sebagai pemberi pakan, karena alat ini akan memberi makan ikan secara otomatis dan presisi dari segi takaran.

\section{METODE}

Pelaksanaan program Pengabdian Kepada Masyarakat (PPM) dimulai setelah dilakukan penandatangan kontrak antara ketua pelaksana dengan LP2M Universitas PGRI Adi Buana Surabaya. Langkah awal yang dilakukan adalah koordinasi dengan Mitra dan Kepala Desa Banjarkemantren. Secara umum pelaksanaan program terdiri dari tahapan penerapan dan penyuluhan sosialisasi pemberdayaan masyarakat tentang pengelolaan budidaya ikan lele dengan alat pemberi pakan otomatis.

\section{Survey Lokasi}

Dari hasil survei tampak permasalahan yang perlu segera ditangani yaitu kurangnya penerapan teknologi dalam pengelolaan budidaya ikan lele di Desa Banjarkemantren

2. Persiapan Sarana Dan Prasarana 
Setelah melakukan survey awal dan penetapan permasalahan yang akan diangkat dan diselesaikan di lokasi PPM tim melakukan koordinasi dengan pihak pemerintahan desa dalam hal ini Kepala Desa dan Karang Taruna. Persiapan sarana dan prasana di lokasi dilaksanakan oleh masyarakat dan dibantu dengan mahasiswa Teknik Industri.

3. Pengadaan Alat Dan Bahan

Proses pengadaan alat dan bahan oleh tim pelaksana PPM sepenuhnya telah disiapkan oleh tim dosen dan dibantu oleh mahasiswa. Bahan utama yang diapkan dalam kegiatan ini merupakan penggalian informasi terkait sistem pengelolaan budidaya ikan lele di Desa Banjarkemantren.

4. Penyuluhan

Penyuluhan dilakukan dengan tema besarnya adalah bagaimana warga desa yang mengoperasikan peternakan lele untuk mengaplikasikan alat pemberi pakan otomatis, dan tata cara penggunaan alat.

5. Pemantauan Hasil Pelaksanaan

Pemantauan pelaksanaan dilakukan bulan Maret 2021, setelah satu minggu pelaksanaan penyuluhan dan pelatihan di Desa banjarkemantren. Pemantauan dilakukan dengan cara meninjau langsung ke Desa Banjarkemantren, Pemantauan ini dilakukan oleh tim Teknik Industri, bersama dengan aparat desa dan tim karang taruna.

\section{HASIL DAN PEMBAHASAN}

Pada perancangan perangkat keras (Hardware) ini terdiri dari beberapa perancangan sepeerti perancangan pakan ikan, motor servo, Real Time Clock (RTC), Liquid Crystal Display (LCD) dan dapat dilihat pada gambar berikut.

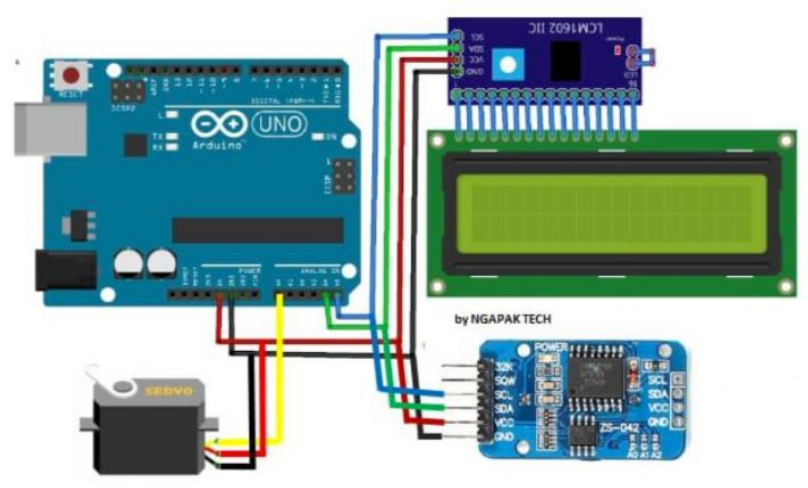

Gambar 1. Rancangan Hardware 
Berdasarkan rangkaian dari Hardware diatas yang dimana RTC DS3231 sebagai pengatur waktu realtime, LCD yang telah terhubung pada pin digital Arduino yang berfungsi sebagai penampil waktu, informasi jumlah pakan, jumlah ketersediaan pakan, motor servo yang telah terhubung ke arduino pada pin 27, yang berfungsi sebagai untuk pembuka dan penutup saluran makanan.

Perangkat lunak yang dirancang menggunakan aplikasi Arduino 1.0.1 pada laptop dengan menggunakan Bahasa $\mathrm{C}$ untuk memberikan gambaran umum jalannya program dan memudahkan pembuatan perangkat lunak. Perangkat lunak ini disusun untuk mengatur kinerja keseluruhan dari system yang terdiri dari beberapa perangkat keras yang telah ditentukan agar system dapat berjalan dengan baik. Berikut merupakan gambar coding/pemrograman perangkat lunak alat pakan ikan otomatis.

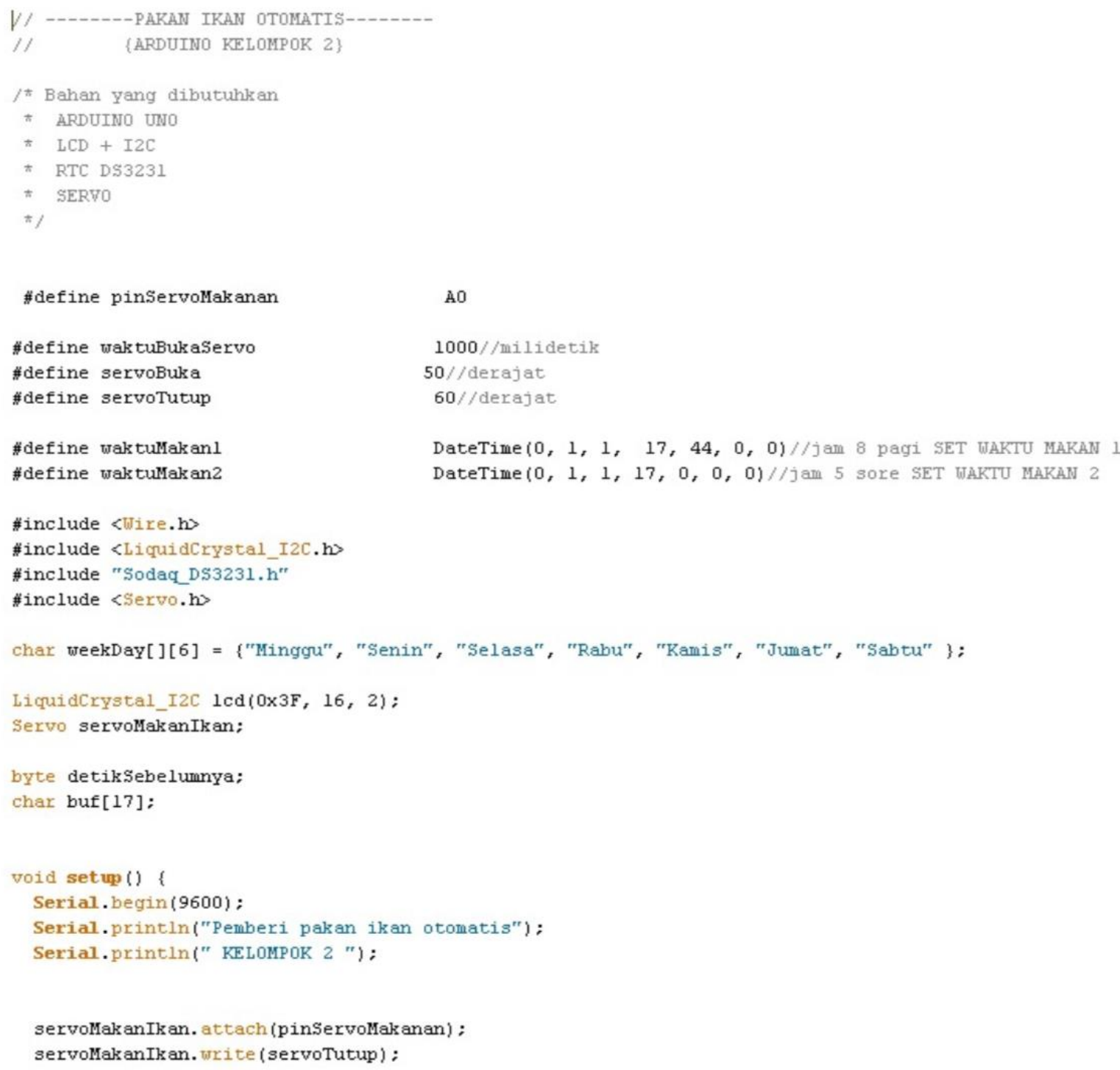

Gambar 1. Perancangan Perangkat Lunak Arduino 
Dari rangkaian tersebut terdiri dari box elektronik untuk meletakkan alat perangkat keras yang disusun sedemikian rupa didalam box. Kemudian terdapat Arduino, motor servo, LCD, RTC, kabel A to B, Kabel Jumper male to female \& male to male, dan juga botol sebagai tempat penampung pakan ikan. Alat ini dirancang sedemikian rupa agar dapat bekerja dengan baik. Dibawah ini terdapat gambar hasil dari rancangan pakan ikan otomatis.

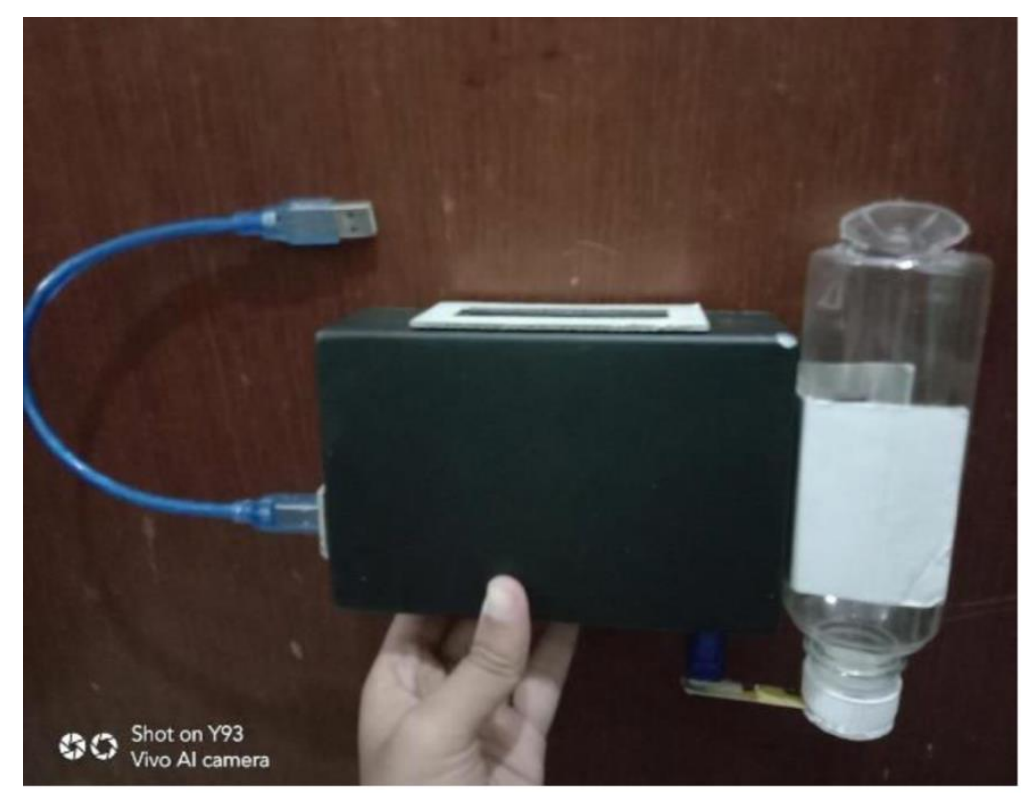

Gambar 2. Prototype alat pakan ikan otomatis

Setelah produk diterapkan pada budidaya lele pada desa Banjarkemantren, produktivitas bisa meningkat hingga 15,3\% di awal fase implementasi. Satu kolam bioflok dapat dipanen lele dengan berat sebanyak 1 ton. Dengan harga lele konsumsi Rp. 15.000,- per kilogram maka akan didapatkan penjualan sebesar Rp. 15.000.000,-. Dengan itu maka pembudidaya lele akan mendapatkan keuntungan sebesar Rp. 10.000.000,-. Hasil tersebut adalah peningkatan dari hasil panen sebelumnya yang hanya mendapatkan keuntungan sebesar Rp. 7.500.000,-.

\section{KESIMPULAN}

Dari hasil pembuatan teknologi tepat guna berupa alat pemberi pakan ikan otomatis, pengelolaan peternakan lele di Desa Banjarkemantren menjadi semakin efektif dan efisien. Ada beberapa biaya yang dapat ditekan dengan penggunaan alat ini, antara lain biaya tenaga kerja untuk pemberi pakan, dan biaya pakan, karena pakan yang diberikan akan menjadi lebih tepat jumlahnya. Dengan alat ini, produktivitas akan semakin meningkat karena pemberian pakan menjadi lebih tepat waktu. Penerapan teknologi tepat guna di desa banjarkemantren akan memberikan dampak yang besar dari segi perekonomian desa, karena dengan produktivitas yang meningkat, maka penjualan lele dari desa banjarkemantren akan meningkat. 


\section{DAFTAR PUSTAKA}

Abdullah, S., \& Priyati, A. (2016). Aplikasi Mikrokontroler Arduino Pada Sistem Irigasi Tetes Untuk Tanaman Sawi (Brassica Juncea). Jurnal Ilmiah Rekayasa Pertanian Dan Biosistem, 4(2), 228 238.

Erawati Dewi, L. J. (2012). Media Pembelajaran Bahasa Pemrograman C++. Jurnal Pendidikan Teknologi Dan Kejuruan, 7(1). https://doi.org/10.23887/jptk-undiksha.v7i1.31

Hughes, J. M. (2016). Arduino : a technical reference: a handbook for technicians, engineers, and makers. 195.

Lazuardi, \& Sudarto, H. (2017). Pengaruh Pemberian Pakan dengan Dosis Berbeda Terhadap Pertumbuhan Benih Ikan Lele Sangkuriang. Jurnal Ilmiah Respati, 8(1), 2-5. http://ejournal.urindo.ac.id/index.php/pertanian/article/view/234\%0Ahttps://repositories.lib.utex as.edu/handle/2152/39127\%0Ahttps://cris.brighton.ac.uk/ws/portalfiles/portal/4755978/Julius+O jebode\%27s+Thesis.pdf\%0Ausir.salford.ac.uk/29369/1/Angela_Darvill_t

Pramono, H., Pujiastuti, D. Y., Maulana, S., \& Azis, A. (2020). Pendekatan Peningkatan Produksi Lele Pada Kelompok Pembudidaya Ikan Surya Perkasa Desa Gendongkulon, Babat, Lamongan Melalui Implementasi Probiotik Dan Teknologi Pascapanen. Jurnal Layanan Masyarakat (Journal of Public Services), 2(1), 45. https://doi.org/10.20473/jlm.v2i1.2018.45-51

Purwati, S. R., Zulkarnaini, \& Hendrik. (2018). Analisis Usaha Budidaya Ikan Lele Dumbo(Clarias gariepinus) Menggunakan Penerapan Sistem Bioflok Dan Sistem Konvensional Di Keluarahan Palas Kecamatan Rumbai Kota Pekanbaru Provinsi Riau. Jurnal Online Mahasiswa Bidang Perikanan Dan Ilmu Kelautan Universitas Riau, 5(1).

Ramadhan, V. M., \& Trilaksana, A. (2019). PERKEMBANGAN PERIKANAN DARI BUDIDAYA TRADISIONAL KE BUDIDAYA MODERN DI KABUPATEN SAMPANG TAHUN 20032017 Agus Trilaksana. Journal Pendidikan Sejarah, 7(2).

Sundari, R. S., \& Priyanto, Y. A. (2016). Efficiency of Production Factors Aplication On Catfish (Clarias sp) Var. Sangkuriang Hatchery Technology. Jurnal Teknologi Perikanan Dan Kelautan., 7(2), 200-207.

Wahyuni, S., Mudarris, M., Askar, A., Ayusnin, S. R., \& Zain, S. G. (2018). Papakinoto (Penebar Pakan Ikan Otomatis) 'Upaya Peningkatan Produksi Dan Efiisiensi Waktu Budidaya Tambak Ikan Tawar Masyarakat Belawa Kabupaten Soppeng”. Jurnal Pendidikan Teknologi Pertanian, 4(2), 42. https://doi.org/10.26858/jptp.v4i2.6611

Widodo, A. E., Suleman, S., \& Safudin, M. (2019). Pemanfaatan Arduino Untuk Mendeteksi Kelembaban Tanah. EVOLUSI: Jurnal Sains Dan Manajemen, 7(2). https://doi.org/10.31294/evolusi.v7i2.5403 